sprachpolitischen Maßnahmen sein können, sondern eher versuchen, Sprachpolitik als Phänomen der Staatswerdung zu schildern und Gemeinsamkeiten zwischen Kolonialzeit und der Gegenwart aufzuzeigen" (p. 8).

Ansätze, Sprache als Vehikel zur Staatswerdung zu nutzen, gab es wie schon zuvor angemerkt ab etwa 1970. Unter dem Schlagwort der kulturellen Identität kam es auch zu einer Rückbesinnung auf die autochthonen Sprachen. Doch die bisherigen Ergebnisse solcher Kampagnen deuten eher darauf hin, daß es sich um Lippenbekenntnisse handelt.

Zuweilen kommt es zu Programmen, die die Verankerung der lokalen Sprachen in der Bevölkerung zum Ziel haben. Doch selbst dann sind Zweifel bezüglich der Zielsetzung begründet. Rusch verweist in diesem Zusammenhang auf die unterschiedlichen Interessenstrukturen (Staat versus Bevölkerung), die z. B. im Rahmen der Alphabetisierungskampagne in Togo deutlich zutage traten. In dem jüngst erschienenen Buch "Bauern und Staat" macht G. Elwert entsprechend entmutigende Angaben zu seinen Erfahrungen bezüglich einer gesellschaftsformenden und entwicklungstragenden Möglichkeit von Alphabetisierung und Förderung autochthoner Sprachen.

Das alles wirft die Frage auf, ob die Mutmaßung Ruschs, es bestehe in den afrikanischen Staaten ein Interesse an "kultureller wie sozialer Selbstentfaltung" bezogen auf Sprache nicht doch ein realitätsfremder Ansatz ist bzw. zumindest eine entsprechende Verkürzung impliziert. Denn diese Sichtweise unterstellt ein einheitlich geartetes Entwicklungsinteresse in den einzelnen afrikanischen Ländern. Verschiedene Analysen haben jedoch gezeigt, daß das nicht gegeben ist. Und auch das besprochene Buch läßt eigentlich nur das traurige Fazit zu, daß Sprachpolitik heute - ebenso wie während der Kolonialzeit zweckgebunden eingesetzt wird. Bedenklicherweise jedoch nicht in Blickrichtung auf eine umfassende Entwicklung von Staat und Gesellschaft, sondern wie ehedem im Sinne von Herrschaftsstabilisierung und -sicherung.

Thomas Labahn

\title{
Susanne Weigelin-Schwiedrzik
}

\section{Parteigeschichtsschreibung in der VR China, Typen, Methoden und Funktionen}

Veröffentlichungen des Ostasien-Instituts der Ruhr-Universität Bochum, Band 29, Wiesbaden: Otto Harrassowitz, 1984, pp xx, 248 (broschiert), DM 44,-

This doctoral dissertation is not, as the author herself emphasises, about the history proper of the Communist Party of China (CCP), but about the way in which the Party's past has been discussed and publicised in the People's Republic of China (PRC).

The book describes the types and media of historiography and examines the different groups of persons active on several levels in projecting an image of the CCP's history. For this purpose Ms Weigelin-Schwiedrzik has drawn on numerous publications - some 
for restricted circulation within the PRC only - and has also conducted interviews with various Chinese authors engaged in this branch of historical investigation.

The author distinguishes three kinds of Party historiography: official propaganda, mainly engineered by historiographers of the older generation who are closely beholden to the gerontocratic nucleus of the CCP leadership; educational publications, mainly produced by full-time writers whose output is based on and elaborates the broad orientations apparent from the first-mentioned variety, thus buttressing the propagandist message; academic research into CCP history, conducted mainly by younger specialised students writing in smaller journals for the benefit of their betters in categories one and two.

As the CCP's history, from its foundation in 1921 to the present, coincides almost entirely with the political career of Mao Tse-tung, Party historiography in the PRC has fundamentally remained an exercise in vindicating the 'Great Helmsman's ' correct line', giving way but lately to relativisations where deference to the former Chairman is subdued if not abandoned.

Ms Weigelin-Schwierdrzik sees Party historiography in the PRC at the interface of two contradictory tendencies, each predicated on, yet also destructive of, the other. The Revolution demands hard, sustained effort, to achieve prosperity after power has been seized, and for this the charisma of the Party's past has to be perpetuated through a lengthening period of normalcy since the violent struggles for supremacy were victoriously completed. Attainment of economic and social advancement, the goals set by the Revolution, will at the same time lessen the need for heroic exertions and, hence, for the charismatic inspiration by the CCP and its leaders. Party historiography of the third kind mentioned above will, as the author surmises, profit from increased prosperity and the resultant 'quotidianisation' of the newly established order, with enhanced opportunities, always within the framework of Party-defined legitimacy, to shift the stress of history writing away from doctrinaire pronouncement and towards more scholarly attempts to render an accurate account of past events.

More work will have to appear in the PRC to confirm such hopes, for as long as the Party remains the only vessel in which the Laws of History are allowed to attain their epiphany, generations of [future] Party historians will continue as handymen, writing and rewriting the sacred annals of the Party's unending, and implacably 'correct', advance into infinity.

Regrettably, some interesting methodological problems have only received limited attention, such as the theoretical efforts to adapt the Marxian concept of proletarian revolution to tiers-mondiste requirements as well as the occasionally bizarre attempts of orthodox historians at periodisation of Chinese history after the fashion of Stalinist historical materialism?.

Those interested in an introduction to CCP historiography do, however, owe a debt of gratitude to the author who, borne along by a declared interest in explaining to herself the reasons for the subservience of Party historiography to political orthodoxy, has worked the trite subject matter with admirable tenacity.

Wolfgang Kessler 